\title{
$\mathrm{N} \circ \mathrm{te}$
}

\section{Nucleotide sequence of the gene required for maturation of 763 proteinase of Lactococcus lactis subsp. cremoris NCDO 763}

\author{
Mayumi KiwaKI ${ }^{1 *}$, Haruo Ikemura ${ }^{1}$ and Akikazu Hirashima ${ }^{2}$ \\ ${ }^{1}$ Yakult Central Institute for Microbiological Research, \\ Kunitachi, Tokyo 186-8650, and \\ ${ }^{2}$ Yakult Pharmaceutical Industry Co., 5-13-5, \\ Shinbashi, Minato-ku, Tokyo 105-0004, Japan
}

In many kinds of lactic acid bacteria, cell wall-bound proteinases are responsible for the initial degradation of caseins and are important for sufficient growth of the bacteria in milk. The proteinase genes ( $p r t P$ ) of Lactococcus lactis strains were investigated intensively and it was found that they are mostly located on plasmids different in size but closely related to each other (1-3). Similar proteinase genes and their products are also found in Lactobacillus species (4-7). It has been shown that a maturation gene (prtM) located immediately upstream of and in the opposite direction to $\operatorname{prtP}$ is required for the processing of the precursor of PrtP into an active enzyme $(8,9)$.

During the course of a study to characterize 763 proteinase $(\operatorname{Pr} P)(1)$, we subcloned a DNA fragment derived from the proteinase plasmid pLP 763 (1) encompassing HindIII to Pst I (designated as pHD2) (Fig. 1.b).
As shown in Fig. 1, the transformant of L. lactis YIT 2081 with $\mathrm{pHD} 2$ expressed as much proteinase activity as that with the parental plasmid did, whereas the transformant with a plasmid lacking the fragment of Hind III and Nru I from pHD2 (designated as pHDN) did not (Fig. 1.c). This indicates the importance of ORF1 for the expression of enzymatically active 763 PrtP by the bacteria.

In order to further analyze the relationship between the two genes, we sequenced the flanking region of ORF1. As shown in Fig.1, ORF1 was found to comprise 900 nts. There was a non-coding region consisting of 319 nts between ORF1 and the 763 prtP gene, and the promoter and SD sequences were found to be in the opposite direction of $763 \mathrm{prtP}$. Comparison of the nucleotide sequence of ORF1 with those of the prtM genes from $L$. lactis strains Wg 2 (8) and SK11 (9) revealed (a)

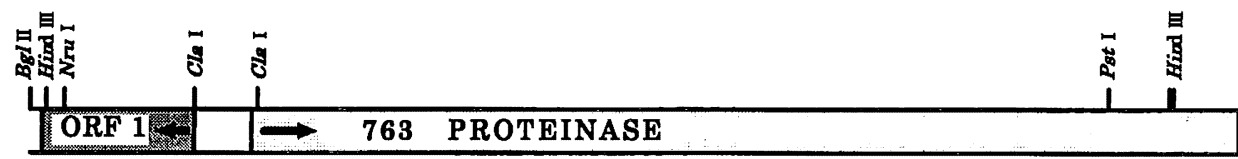

(b)

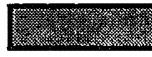

Phenotype
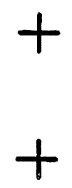

(c)

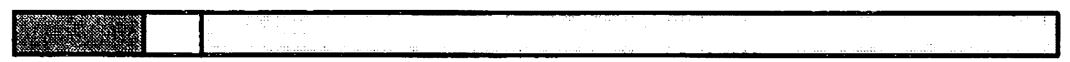

Fig. 1. Relationship between the DNA fragments subcloned from pLP 763 plasmid and proteinase phenotypes. (a) A DNA fragment encompassing Bgl II and the end of 763 prtP, a positive control, (b) a fragment encompassing Hind III to Pst I in pHD2, and (c) a fragment encompassing Nru I to PstI in pHDN. Arrows indicate the positions and transcriptional directions of the two genes. The phenotypes of the strains carrying these plasmids on glucose-citrate milk agar (1) are shown at the right.

* Corresponding author. Phone. 042 - 577 - 8960;

Fax. 042-577-3020 
differences of only one nucleotide with $\mathrm{Wg} 2$, and 2 nucleotides with SK11. These differences, respectively, resulted in only one amino acid substitution at the $46^{\text {th }}$ position from the $\mathrm{N}$-terminus of the deduced protein sequence. From these results, we conclude that ORF1 is the gene that encodes PrtM for pLP 763. The similarities of the nucleotide sequences and the same gene organization of prtM and prtP from the proteinase plasmids of three strains suggest that they were derived from a common ancestral prototype.

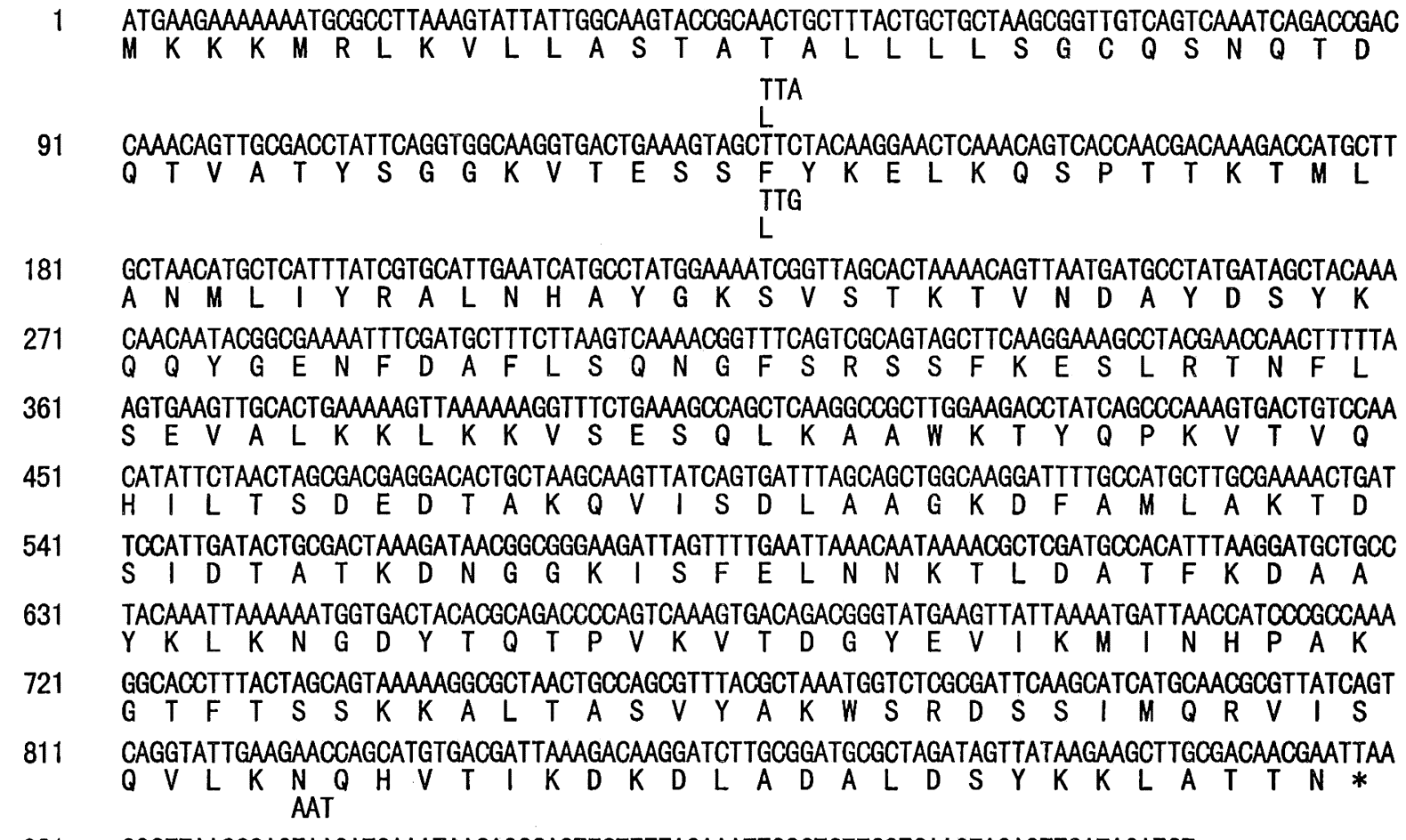

901

GGCTTAACCGAGTAAGATGAAATAACAGCCAGTTCTTTTAGAAATTGGCTCTTCGTCAAGTAGAGTTGATAGATCT

Fig. 2. Nucleotide and deduced amino acid sequences of the gene required for the maturation of 763 proteinase. Sequencing was performed as described previously (1). The different nucleotides and amino acid residues of the maturation genes of $\mathrm{Wg} 2$ (8) and SK11 (9) compared to that of 763 are shown above and below the sequences, respectively.

\section{REFERENCES}

1.M. Kiwaki, H. Ikemura, M. Shimizu-Kadota, and A. Hirashima, Molecular characterization of a cell wallassociated proteinase gene from Streptococcus lactis NCDO 763. Mol. Microbiol., 3 , 359-369 (1989).

2.J. Kok, K. J. Leenhouts, A. J. Haandrikman, A. M. Ledeboer, and G. Venema, Nucleotide sequence of the cell wall proteinase gene of Streptococcus cremoris Wg 2. Appl. Environ. Microbiol.,54, 231-238 (1988).

3.P. Vos, G. Simons, R. J. Siezen, and W. M. de Vos, Primary structure and organization of the gene for a procaryotic, cell envelope-located serine proteinase. J. Biol. Chem., 264, 13579-13585 (1989).

4.P. Laloi, C. Atlan, D. Gilbert, and R. Portalier, Cell wall associated proteinase of Lactobacillus delbrueckii subsp. bulgaricus CNRZ 397. Appl. Microbiol. Biotechnol., 36, 196-204 (1991).

5.H. Naes, and J. Nissen-Meyer, Purification and N-terminal amino acid sequence determination of the cell wall bound proteinase from Lactobacillus paracasei subsp. paracasei. J. Gen. Microbiol. 138, 313-318
(1992).

6.C. Martin-Hernandez, A. Alting, and F. Exterkate, Purification and characterization of the mature, membrane associated cell-envelope proteinase of Lactobacillus helveticus L89. Appl. Microbiol. Biotechnol. 40, 828-834 (1994).

7.M. Kojic, D. Fira, A. Banina, and L. Topisirovic, Characterization of the cell wall-bound proteinase of Lactobacillus casei HN14. Appl. Environ. Microbiol. 57, 1753-1757 (1991).

8.A. J. Haandrikman, J. Kok, H. Laan, S. Soemitro,A. M. Ledeboer, W. N. Konings, and G. Venema, Identification of a gene required for maturation of an extracellular Lactococcal serine proteinase. J. Bacteriol. 171, 2789-2794 (1989).

9.P. Vos, M. van Asseldonk, F. van Jeveren, R. Siezen, G. Simons, and W. M. de Vos, A maturation protein is essential for production of active forms of Lactococcus lactis SK11 serine proteinase located in or secreted from the cell envelope. J. Bacteriol. 171, 27952802 (1989) 


\section{Lactococcus lactis subsp. cremoris NCDO 763 の生産する \\ 763 プロテアーゼの成熟に必要な遺伝子の塩基配列}

木脇真祐美 ${ }^{1}$, 池邨治夫 ${ }^{1}$, 平島昭和 ${ }^{2}$

${ }^{1}$ 株式会社 ヤクルト本社中央研究所, ${ }^{2}$ 現ヤクルト薬品工業株式会社

要 約

Lactococcus lactis subsp. cremoris NCDO 763 株のプラスミドpPL 763 において, 細胞壁結合 型プロテアーゼ遺伝子の上流にそのプロテアーゼ活性の発現に必要な遺伝子 $(p r t M)$ が検出され た。その塩基配列解析の結果, Lactcoccus lactis Wg 2 および SK11 で報告されている prtMと900 塩基中それぞれ 1 および 2 塩基を除き相同であった。

Key words : Lactococcus lactis subsp. cremoris NCDO 763, cell wall-bound proteinase, maturation gene ( $p r t M)$ 